DARIUSZ PIEchota

Uniwersytet w Białymstoku

\title{
Wątki ekologiczne w prozie modernistów
}

Dominika Oramus, charakteryzując współczesną fantastykę, podkreśliła, że gatunek ten stworzył język, który „pozwala mówić o traumach końca XX wieku: dehumanizacji, późnym kapitalizmie z jego przesadnym marketingiem, chaosie informacyjnym, maltretowaniu dzieci, seryjnych zabójcach, zatruciu środowiska" (Oramus 2010: 16). Badaczka zwróciła uwagę, że wykreowany w niej świat przedstawiony nie jest mimetyczną kopią rzeczywistości, lecz wykazuje istotne podobieństwa do literatury realistycznej, ekstrapolując pewne tendencje kulturowe bądź aktualne problemy społeczne (Oramus 2010: 224). Fantastyka odgrywa szczególną rolę w burzliwych okresach, gdyż jest „[...] środkiem wyrażania refleksji nad kulturą i stanem wiedzy o kulturze we współczesnym autorowi świecie" (Oramus 2010: 184). Trop ten wydaje się też bardzo istotny dla rozważań dotyczących literatury drugiej połowy XIX wieku, kiedy to popularnością zaczęly cieszyć się takie gatunki jak: utopia, science fiction, the future novels (Bobrowska 2004: 207-232).

Przypomnijmy, że pozytywiści byli zafascynowani rozwojem nauk przyrodniczych oraz technicznych (zob. Malik 2003: 397-405; Gielata 2011). To na podstawie nowoczesnych wynalazków wybiegali w przyszłość, snując utopijne wizje doskonałego społeczeństwa, które na drodze postępu dokonywało przeobrażenia świata. Pisarze epoki pary i elektryczności rozpoczęli eksperymenty z czasem, zastanawiając się, jak będzie wyglądała ludzkość za sto lat. W jaki 
sposób zmieni się ich styl życia dzięki kolejnym odkryciom technologicznym (zob. Bobrowska 2004: 207-232; Piechota 2015: 69-82)? Interesujący wydaje się fakt, że futurologiczne opowieści pozytywistów pomijały wątki niekontrolowanego rozwoju nauki oraz jej wpływu na środowisko naturalne (Bobrowska 2004: 231; Piechota 2015: 80-81). Dopiero u schyłku XIX wieku wraz z nasilającymi się nastrojami dekadenckimi oraz pesymistyczną filozofią Schopenhauera moderniści zaczęli dostrzegać destrukcyjny wpływ cywilizacji przemysłowej nie tylko na życie jednostki, ale również na środowisko. Unoszący się dym z fabryk, spływające do rzek toksyczne substancje z zakładów przemysłowych były czytelnym symptomem nadchodzącej katastrofy ekologicznej. Nowoczesne miasta stały się przestrzenią dezintegracji, w której to człowiek utracił bezpośredni kontakt z naturą, co miało negatywny wpływ na jego egzystencję (Kolbuszewski 1992: 112-115). Mimo postępu technicznego warunki życia mieszkańców la belle époque nie uległy poprawie. Wielogodzinna, wyczerpująca praca w najgorszych warunkach sanitarnych, zwiększająca się liczba ludności miejskiej potęgowały kontrast między przedstawicielami upper class a robotnikami żyjącymi na granicy ubóstwa. U schyłku XIX wieku narastały społeczne lęki przed zanieczyszczeniem powietrza, zatruciem wody czy zniszczeniem krajobrazu (Paczoska 2010: 65). Wielkie miasta przemysłowe, postrzegane jako demoralizujące siedlisko zła, stały się synonimem pustki i entropii. W literaturze modernistycznej często pojawiały się obrazy miasta antywitalnego, w którym eksponowano wizerunek natury chorej, rachitycznej, zarażonej śmiercią (Gutowski 1993: 190). Wielkie metropolie często opisywano w konwencji turpistycznej; eksponowano brzydotę, niejednokrotnie porównywano je do polipa, postępującego nowotworu przyczyniającego się do degradacji moralnej jednostki. W charakterystyce krajobrazu przemysłowego wprowadzano symbolikę śmierci, która dotyczyła nie tylko bohaterów, ale również świata natury. Często pojawiały się w nim rachityczne, pochylone drzewa pozbawione liści, krzewy w stanie rozkładu (np. w Ziemi obiecanej Władysława Stanisława Reymonta). W ośrodkach przemysłowych rzadko można usłyszeć radosny śpiew ptaków, a jedyne stworzenia pojawiające się w powieściach to psy i koty, będące pupilami bogatych pań i panów (Piechota 2020: 113-130).

Szybko dostrzeżono, że nowoczesna cywilizacja zagrażała jednostce oraz kulturze (Podraza-Kwiatkowska 2001: 43-44). Okazało się, że postęp moralny nie idzie w parze ze wzrostem dóbr materialnych społeczeństwa. Co więcej, ostrzegano przed duchową degeneracją człowieka zanurzonego w świecie maszyn (Szurek 1988: 186). Niepokój potęgował również dynamiczny rozwój fizyki w ostatnich dwóch dekadach XIX wieku. Obawiano się, że w jednym z licznych europejskich laboratoriów trwają prace nad śmiercionośną technologią, która 
znajdzie zastosowanie militarne i odmieni sposób, w jaki toczone będą wojny (Oramus 2020: 113). Nie dziwi zatem fakt, że u schyłku epoki wiktoriańskiej pojawiły się futurystyczne utwory o charakterze katastroficznym, zapowiadające międzynarodowy konflikt zbrojny ${ }^{1}$. Narastający kryzys wartości odzwierciedlał zagubienie człowieka, egzystującego u schyłku epoki pary i elektryczności, poszukującego celu oraz sensu życia. Nastroje pesymistyczno-dekadenckie korespondowały także z przekonaniem o nieuchronnym starzeniu się kultury europejskiej, o czym pisał w fundamentalnym dziele Zmierzch Zachodu Oswald Spengler (1918). Niemiecki filozof twierdził, że rozwinięty Zachód stał się cywilizacją zdegenerowaną, czekającą na nowych barbarzyńców ze Wschodu, którzy zajmą jej miejsce (zob. Oramus 2020: 114). Popularnością cieszyły się również teorie o szybkim wygasaniu słońca, a tym samym - zamarzaniu naszej planety (Podraza-Kwiatkowska 2001: 45). Lęk przed śmiercią czy uprzedmiotowieniem, osłabienie woli, porzucenie wiary w przyszłość, melancholia były powszechne w świadomości pokolenia epoki fin de siècle.

Fascynacje modernistów wątkami katastroficznymi, zapowiadającymi nadciągający kres cywilizacji, stały się początkiem poszukiwania azylu. Miejscem takim okazał się świat natury, będący przestrzenią kontemplacji, oczyszczenia czy poszukiwania utraconej więzi ze wszechświatem. Popularnością zaczęły się cieszyć utopie agrarne (Pułka 1996: 113), krytykujące kulturę przemysłową, której dynamiczny rozwój nie tylko wpłynął destrukcyjnie na życie jednostki, ale także przyczynił się do głębokich zmian w świecie przyrody. Skutecznym remedium stało się zatem zerwanie więzi z toksyczną przestrzenią metropolii oraz powrót na łono natury. Warto podkreślić, że w miastach przemysłowych coraz częściej zakładano ogrody (garden cities) będące próbą połączenia wsi i miasta jako początku nowej cywilizacji, wolnej od zagrożeń rewolucji przemysłowej, zwłaszcza od problemów mieszkaniowych (Gutowski 1993: 211; 2004: 208).

W literaturze modernistycznej pojawiają się katastroficzne obrazy ukazujące zagładę miast-molochów. Zainteresowanie twórców wątkami apokaliptycznymi jest niezwykle interesujące z perspektywy badań ekokrytycznych, poszukujących źródeł współczesnych problemów związanych ze zmianami klimatycznymi oraz coraz częściej występującymi katastrofami ekologicznymi (powodzie, susze, huragany), deforestacją czy cykliczną zagładą kolejnych gatunków zwierząt.

1 The Great War of 189-: A Forecast (Wielka wojna roku 189-: Prognoza) P.H. Colomba (1895); The Captain of The „Mary Rose” (Kapitan „Mary Rose”) Williama Lairda Clowesa (1892); The Final War (Wojna ostateczna) Louisa Tracy'ego (1893); The Crack of Doom (Dzień gniewu) Roberta Cromiego (1895) czy Wojna światów George’a Herberta Wellsa (1898) (Oramus 2020: 116). 
W niniejszym szkicu pragnę skoncentrować się na analizie czterech utworów (Fragment pamiętnika Gustawa Daniłowskiego, Cmentarzysko Władysława Stanisława Reymonta, Wieści znikąd Williama Morrisa, Memoriał doktora Czang-Fu-Li Antoniego Langego), ukazujących różne oblicza zagłady. W opowiadaniu Daniłowskiego występuje ona marginalnie, w jej opisie autor uchwycił lęki i obsesje towarzyszące drapieżnie rozwijającej się cywilizacji przemysłowej (Podraza-Kwiatkowska 2001: 254-255). W noweli Reymonta rewolucja jest początkiem końca świata. W obu utworach kluczową rolę odgrywa kontekst historyczny oraz ideologiczny związany z narastającym konfliktem klasowym (między robotnikami i kapitalistami) oraz falą strajków towarzyszących rewolucji w 1905 roku (Utkowska 2004: 273-295). Eksplozja terroru, anarchii oraz zbrodni obnażyła klęskę europejskiej kultury i cywilizacji (Sztachelska 1997: 171; Tyszka 2005: 19-30).

W przeciwieństwie do Fragmentu pamiętnika przyroda u Reymonta odradza się na zgliszczach dawnej fabryki. Podobny wątek odnajdujemy w powieści Wieści znikąd Williama Morrisa, w którym to Anglia w drugiej połowie XXI wieku przypomina utopię agrarną. Ostatnim omawianym utworem będzie Memoriał doktora Czang-Fu-Li Langego, którego akcja rozgrywa się w XXVII wieku i opisuje świat, który uległ transformacji na skutek zmian klimatycznych. Nieprzypadkowo w kontekście polskich pisarzy pojawia się postać Morrisa, który podobnie jak John Ruskin krytykował życie w uprzemysłowionych regionach Anglii. Cywilizacja industrialna nie tylko jest odrażająca pod względem moralnym i estetycznym, ale przede wszystkim niszczy bezpowrotnie krajobraz, roślinność i zwierzynę, zatruwa rzeki oraz powietrze, narusza harmonijną równowagę między człowiekiem i przyrodą (Jedlicki 2000: 36). Pierwsze tłumaczenia pism Morrisa i Ruskina pojawiają się w Polsce w latach osiemdziesiątych XIX wieku, a wysyp nowych przekładów następuje w pierwszym dziesięcioleciu XX wieku (Paczoska 2010: 61). Dlatego też idee powrotu do natury połączone z krytyką uprzemysłowionej, zurbanizowanej Europy szybko zyskały popularność na starym kontynencie. Wiązało się to także z nostalgią za światem przednowoczesnym, któremu towarzyszyło poszukiwanie tego, co utracone (Czeczot, Pospiszyl 2018: 37).

Apokaliptyczna wizja zagłady cywilizacji pojawia się we Fragmencie pamiętnika Daniłowskiego (1906). Akcja utworu rozgrywa się w Warszawie, a jej bohaterem jest poeta, którego egzystencja koncentruje się na pisaniu wierszy, uczęszczaniu do teatru oraz udziale w licznych spotkaniach towarzyskich mocno zakrapianych alkoholem. Mężczyzna mieszka w kamienicy, a jego sąsiedzi reprezentują środowisko filistrów, pogardzanych przez bohemę artystyczną. To oni są źródłem jego udręk, apatii czy nawet niemocy twórczej. Bohater czuje 
się osaczony przez miasto, podświadomie rozmyśla nad wyjazdem ze stolicy. Interesujący wydaje się również sposób wprowadzenia wątku fantastycznego w utworze. Daniłowski nie wykorzystuje popularnych chwytów, jakimi były wizje senne, halucynacje, które „służyły poszerzeniu wizji świata o zjawiska niedające się racjonalnie uzasadnić” (Bobrowska 2004: 209). Obsesyjne, pesymistyczne myśli mężczyzny w połączeniu z uciążliwymi sąsiadami głośno słuchającymi muzyki z gramofonu stają się impulsem do snucia katastroficznej wizji zagłady ludzkości:

Chwilami napastują mnie przypuszczenia, że kiedyś cała treść inteligencji ludzkiej wcieli się w maszyny, a człowiek przekształci się w jakiś przewód pokarmowy, polip wkręcony w ich tryby, automat całkowicie zależny od tych stalowych istot, ściśle wyrachowanych, dokładnych i obojętnych, jak lodowiec. Dusza zniknie, stając się jakąś zdolnością szczątkową, a zbyteczne jej wzruszenia, będą wywoływały takie wrażenia podziwu i komizmu, jak dziś osoba strzygąca uszami (Daniłowski 1906: 30).

Mężczyzna obawia się, że monotonna praca w zakładach przemysłowych przyczyni się do degradacji moralnej człowieka, który, metaforycznie mówiąc, przeobrazi się w maszynę. Utrata podmiotowości wpłynie destrukcyjnie również na rozwój kultury narodowej, która okaże się zbędna w codziennej egzystencji. Kulminacją obaw bohatera staje się wizja senna, ukazująca apokaliptyczny scenariusz końca świata:

Czasem majaczy mi się, niby we śnie, jak dźwiga się naprzód morderczym pochodem kamienne miasto, miażdżąc rośliny, ptaki i zwierzęta. Ceglaste, jak krew spiekła, mury zagrodzą glob cały. Ziejące dymem straszliwe gardziele kominów oślepią słońce. Centralna stacja elektryczna nerwami drutów rozsiewać będzie głosy i światła. Centralny warsztat siecią rur i szyn będzie dostawiał porcje odzieży i strawy. Centralny buduar stanie się zakładem antropotechnicznym, przy nim w centralnej hali jeden wielki motor będzie niańczył w gumowych łapach niemowlęta, a w centralnym grobie mechaniczne świdry druciane stoczą ciała umarłych. W ocembrowanych morzach legnie trupem woda i zdławione wichry pod krzyżami mostów żelaznych. Padną na płask góry zryte, prócz jednej centralnej, skąd potworna pompa będzie ssawkami wtłaczała w studnie kamienic określone dawki powietrza (Daniłowski 1906: 30). 
A potem wszystko zleje się razem - mury w skałę monolitu, kominy w krater olbrzymi, bogacze we wzdęty, jak balon, brzuch, urzędnicy w ogólny „sitzfleisch” ludność robocza w jedną, jak sosna opalona, zaczerniałą rękę; my, literaci, w olbrzymią szczotkę najeżoną piórami i przyśrubowaną do machiny rotacyjnej, a Rudzcy wówczas w kopułę łba palną sobie $\mathrm{z}$ armaty, bo życie stanie się śmiertelnie jednostajne i nieciekawe zupełnie (Daniłowski 1906: 31).

W opisie katastrofy ekologicznej Daniłowski posługuje się poetyką ekspresjonistyczną, cechującą się dynamizmem obrazowania (Stępnik 1988: 28). Tak naprawdę nie znamy przyczyny nadciągającej apokalipsy. Prawdopodobnie jest nią wybuch $\mathrm{w}$ jednej $\mathrm{z}$ fabryk ${ }^{2}$, który w szybkim tempie rozszerza się na cały glob ziemski. Wraz z destrukcją przestrzeni miejskiej giną ptaki i zwierzęta. Kadr wypełniają obrazy zastygłej krwi. Atmosferę grozy oraz przerażenia potęguje unoszący się dym z kominów fabryk oraz hałas dobywający się z przepalonych kabli i wybuchających maszyn. Zdeformowana przestrzeń wywołuje przerażenie wśród mieszkańców, a ograniczony dostęp do świeżego powietrza wzbudza uczucie osaczenia. Początkowo efekt ruiny i chaosu w opowiadaniu Daniłowskiego występuje w wersji dynamicznej, którą intensyfikują nagromadzone czasowniki. W wyniku globalnej katastrofy świat umiera, a na gruzach powstaje odrażający, martwy monolit. W scenerii tej uwagę czytelnika przykuwa nie tylko cisza, ale również estetyczna degradacja tego miejsca.

Apokaliptyczny wizerunek przestrzeni miejskiej pojawia się również w opowiadaniu Cmentarzysko (1907) Reymonta. Utwór ten wpisuje się w cykl nowel (Zabiłem!, Czekam..., Na krawędzi) ukazujących obrazy zrujnowanych fabryk, konających maszyn. Metropolie porównywane do potworów czy polipów budzą skojarzenia z nekropolią (Utkowska 2004: 127). Dla pisarza rewolucja z owładniętym żądzą zemsty tłumem była cywilizacyjną apokalipsą zagrażającą porządkowi społecznemu (Utkowska 2004: 127).

Nowela Cmentarzysko rozpoczyna się strajkiem w fabryce, który w szybkim tempie obejmuje całą przestrzeń miasta. Bunt robotników przeobraża się w rewolucję porównywaną do gwałtownych zjawisk atmosferycznych: „Burza się rozpętała nad światem, orkan się zerwał i w swój wir straszliwy porywał

2 Motyw ten pojawia się również w rękopisie Śmierć maszyny (1903) Reymonta. W utworze tym, dzięki zastosowanej przez autora animizacji, maszyna utożsamiana jest $\mathrm{z}$ potworem, odpowiedzialnym za śmierć tysięcy ludzi. Uczłowieczone monstrum, jak pisze Beata Utkowska, bierze odwet za wieloletnie cierpienie. Kreacja świata przedstawionego budzi skojarzenia z apokaliptycznymi wizjami zagłady świata (Utkowska 2004: 126-127). 
ludzi i rzeczy, kłębił się, miotał, miażdżył i zabite rozsiewał po ziemi wiecznie głodnej” (Reymont 1907: 137). Żywioł ten dokonuje spustoszenia w przestrzeni miejskiej, pochłaniając kolejne ofiary. Co więcej, „w lepkich od krwi kanałach ulice miotały się huragany; stawały się mordy, wrzały bitwy mordercze, wybuchały szaleństwa" (Reymont 1907: 138-139). W opisie rewolucji dominuje antynomiczna wizja świata, w której pisarz eksponuje uczucie cierpienia oraz bólu. Kluczową rolę odgrywa również kolorystyka. Uwagę czytelnika przykuwa zastygła, lepka krew, dodatkowo potęgująca atmosferę nadciągającego kresu. Miasto przeobraża się w „cmentarzysko dusz” (Reymont 1907: 150):

Umierało wszystko, ale fabryki jeszcze żyły; tylko te potwory, oblegające miasto stadem głodnych bestii czaiły się w złowrogim milczeniu. Wznosiły się, jak ołtarze Molocha cierpliwie oczekującego na zwycięzców. U ich stóp, w błocie krwi i łez wrzały walki śmiertelne, mrowiło się oszalałe plemię ludzkie, a one zdawały się pławić rozkoszą odrętwiałe cielska w jękach i krwi (Reymont 1907: 139-140).

Widmo katastrofy odzwierciedla także opozycja: świat przemysłu vs. świat ludzi. W opisie fabryk autor Cmentarzyska posługuje się poetyką turpizmu. Miejsca te porównane zostają do potworów, czyhających w milczeniu na kolejne ofiary. Wydają się dominować nad walczącymi ludźmi, którzy wyzbyli się jakichkolwiek zasad moralnych.

Podobnie jak u Daniłowskiego, świat zmierza ku kosmicznej zagładzie, do której doprowadziła zdegenerowana ludzkość. Kres cywilizacji jest nieunikniony. Jednak w opowiadaniu Reymonta po agonii następuje odrodzenie:

I znowu powróciły wiosny, znowu ożyły puste, stratowane pola, znowu wróciło wygnane życie przyrody i wraz ze słońcem, nie przyćmiewane dymami, siało po ziemi błogosławiącą dłonią weselne szczęście istnienia, że zaroiły się pustki, ozieleniały ruiny, a lasy, co niegdyś ledwie były dojrzane ze szczytów złotych bram, zbliżały się już coraz bujniejszym kręgiem, szły ze wszystkich stron szumiącą chmurą zieleni, szły rozśpiewane świergotem ptactwa i dyszące upojeniem rostu, okrążały mury, zdobywały zwaliska, wdzierały się triumfalnie w ulice, że już z popękanych bruków chlustały smukłe brzozy w białe gzła przyodziane, już jałowce pełzały rynsztokami, już leszczyny gąszczem zasiadały w cieniu złotych portyków, już sosny wynosiły się dumnie przez potrzaskane zręby, a potężne dęby wżerały się korzeniami w marmury i gdzieniegdzie, przez zapadłe dachy, dzika grusza wychylała 
o wiośnie okwiecony, woniejący czub, owiany pszczelim brzękiem (Reymont 1907: 154).

W noweli Reymonta przyroda odradza się w mieście, co koresponduje ze światopoglądem pisarza. Już od publikacji Chłopów autor wierzył, że dzieje świata oparte są na nadrzędnym mitycznym porządku, w którym obowiązuje „czas cykliczny”. Jak podkreśla Beata Utkowska:

Porządek ten opiera się na micie wiecznego powrotu: niezmiennie powtarzalny jest rytm pór roku i kolejnych miesięcy, rytm prac ludzkich związanych z przyrodą oraz rytm obrzędów, świąt i zwyczajów narzuconych przez kulturę i moralność społeczności (Utkowska 2004: 287).

W opisie przyrody pisarz posługuje się nie tylko animizacją, ale również antropomorfizacją. Wraz z budzącą się do życia naturą w przestrzeni miasta obserwujemy zachodzące transformacje, nasuwające skojarzenia $z$ baśniowym światem. Majestatyczne drzewa rozrastają się w pobliskim lesie, emanując bogactwem i różnorodnością. Z perspektywy fabryki wydaje się, że „zbliżają się” one do miasta. Na jej dawnych gruzach wyrastają sosny oraz dęby. Panuje tutaj cisza, której nie zakłócają już odgłosy wydobywające się z kominów fabryk:

Umarłe cmentarzysko miasta, zetlały trup człowieczej potęgi, okrył się królewskim płaszczem puszczy pełnej słonecznego waru życia, pełnej szumów, lśnień, kwitnień, cichych poczynań, śpiewu ptaków, miłosnych szałów, bełkotu wód, upajających śmierci, i tajemniczych, niezgłębionych szeptów przyrody (Reymont 1907: 155).

O zwycięstwie natury nad destrukcyjną cywilizacją świadczy również śpiew ptaków, które powróciły na teren dawnego ośrodka przemysłowego. Wizja odradzającego się środowiska naturalnego nasuwa skojarzenia ze współczesną ekologiczną urbanistyką, zgodnie z którą bloki mieszkalne czy drapacze chmur są pokrywane bujną roślinnością, tworząc tzw. wertykalny las (Borawski 2018: 138-139). Na tarasach w „zielonych” wieżowcach zaprojektowanych przez Stefano Boeriego w Mediolanie rosną drzewa, krzewy i pnącza (Borawski 2018: 138-139). Miejsce to podświadomie odzwierciedla odwieczne marzenia człowieka o bliskim kontakcie z przyrodą. Wraz z zieloną elewacją w budynkach tych pojawili się nowi lokatorzy (kilka gatunków ptaków i owadów). Projekt Boeriego wpisuje się w nowoczesną politykę dążącą do zrównoważonego rozwoju miast, potrzebujących większej ilości tlenu oraz „gęstszego zielonego buforu, który będzie oczyszczać coraz bardziej zanieczyszczone powietrze” (Borawski 2018: 139). 
Motyw odradzającej się natury na zgliszczach cywilizacji przemysłowej obecny jest także w powieści Wieści znikąd (News from Nowhere, 1890) Morrisa, która szybko zdobyła popularność wśród czytelników zarówno w kraju (w pierwszym roku sprzedano 8 tysięcy egzemplarzy w Anglii), jak i za granicą. Do 1898 roku powstały tłumaczenia powieści na języki francuski, niemiecki oraz włoski (Leopold 2009: VIII). Jednym ze źródeł inspiracji stała się powieść utopijna W roku 2000 (Looking Backward) Edwarda Bellamy’ego, będąca dziewiętnastowiecznym amerykańskim bestsellerem. Pod koniec wieku była to druga najchętniej kupowana powieść w Ameryce po Chacie Wuja Toma (1852) Harriet Beecher Stowe (Leopold 2009: XI-XII). Bohaterem powieści Bellamy’ego jest Julian West, który budzi się z długiego snu w Bostonie w 2000 roku. Mężczyzna odkrywa, że w nowej Ameryce nie istnieje zjawisko biedy, korupcji, mieszkańcy zaś nie znają żadnych przewlekłych chorób. Każdy obywatel po ukończeniu 21 roku życia zostaje wcielony do przemysłowej „armii”, aby pomnażać narodowe bogactwo. Nowoczesne społeczeństwo pogrążone jest w nieustannej konsumpcji, napędzającej przemysłową koniunkturę.

Utopijna wizja Ameryki została skrytykowana przez Morrisa w recenzji opublikowanej na łamach „Commonweal” (Leopold 2009: XII). Autor Lasu za światem podkreślił, że Bellamy skupił się wyłącznie na aspekcie materialnego dobrobytu społeczeństwa. W alternatywnej wizji przyszłości Amerykanin traktuje pracę jako „zło konieczne” i postuluje, aby zredukować dzienną liczbę godzin spędzanych w miejscu zatrudnienia (Leopold 2009: XIV). Z poglądem tym polemizuje Morris, który uważa, że praca powinna być źródłem przyjemności, a człowiek winien otaczać się pięknymi przedmiotami. Autor postuluje także, aby w zakładach przemysłowych obowiązywał czterogodzinny dzień pracy tak, aby każdy pracownik mógł zaspokoić wszystkie potrzeby życiowe. Morris krytykuje również współczesną mu rewolucję przemysłową, w której to maszyny przejęły kontrolę nad człowiekiem (Leopold 2009: XVII). Autor Wieści znikąd tęskni za epoką preindustrialną, kiedy to nie posługiwano się zaawansowaną technologią, a praca miała charakter twórczy. Niewątpliwie jego utwór podejmuje polemikę z powieścią Bellamy’ego.

Futurystyczna wizja Anglii w drugiej połowie XXI wieku w utworze Morrisa przypomina agrarną idyllę (Jedlicki 20oo: 133-138; Paczoska 2010: 61-62). Z przestrzeni Londynu zniknęły dymiące kominy fabryk, a Tamiza przestała być zanieczyszczana toksycznymi odpadami. Mieszkańcy Londynu są ludźmi szczęśliwymi, a wewnętrzny spokój osiągnęli dzięki zerwaniu z konsumpcyjnym stylem życia:

[...] ludzie w ostatnim okresie cywilizacji pod względem produkcji towarów wpadli byli w prawdziwe błędne koło, z którego nie było wyjścia. 
Doszli oni do niesłychanej szybkości w wytwarzaniu towarów, a chcąc produkcji tej zapewnić jak najlepsze pole zbytu, stworzyli bardzo skomplikowany system kupna i sprzedaży, a raczej rynek wszechświatowy, który raz powołany do życia, zmuszał ich do coraz większej produkcji towarów - bez względu na popyt. W ten sposób - obok rzeczy niezbędnych -wytwarzano niesłychaną ilość niepotrzebnych, które pod żelaznym panowaniem tzw. rynku wszechświatowego stawały się równie ważnymi, jak produkty konieczne do życia potrzebne. W ten sposób ludzie uginali się pod strasznym ciężarem pracy, mającym jedynie na celu utrzymanie w ruchu tego nędznego systemu (Morris 1902).

Anglicy zrezygnowali z udziału w wyścigu szczurów i poświęcili się wykonywaniu czynności sprawiających im radość. Priorytetem dla mieszkańców stolicy stało się ograniczenie produkcji do minimum:

[...] wiemy obecnie czego nam potrzeba, to też nie produkujemy więcej, niż nam potrzeba; ponieważ zaś nic nas nie zmusza do produkcji ogromnej ilości bezużytecznych przedmiotów, mamy dosyć czasu i środków na to, aby położyć nacisk na przyjemność podczas produkcji. Wszelka praca, która by nas nudziła jest wykonywana przez niezmiernie ulepszoną maszynerię [...]. Kiedy [...] pewna praca jest zanadto niemiła lub kłopotliwa, zarzucamy ją, obywając się całkowicie bez tego produktu. [...] Każda wykonywana przez nas praca jest ćwiczeniem umysłu i ciała (Morris 1902).

Zmiany te, o których pisze Morris, wpłynęły korzystnie na środowisko naturalne. W Tamizie rybacy łowią łososie, które stanowią podstawowy składnik odżywiania się. Przypomnijmy, że w XIX wieku rzeka ta była skażona, o czym pisał m.in. Henry Mayhew: „W jasnym świetle przypominała kolorem mocną zieloną herbatę [...], była bardziej wodnistym błotem niż błotnistą wodą, a jednak zapewniono nas, była to jedyna woda, którą nieszczęśni mieszkańcy musieli pić” (Wilson 2009: 155). Anglicy w powieści Morrisa zminimalizowali konsumpcję mięsa, a ich posiłki składają się głównie ze świeżych owoców oraz warzyw uprawianych w mieście. Dieta ta wpływa korzystnie na zdrowie Brytyjczyków, opóźniając proces starzenia się.

Utopię agrarną w powieści Morrisa poprzedziła rewolucja w 1952 roku, podczas której to robotnicy domagali się podwyżki płacy minimalnej. Zamieszki na Trafalgar Square szybko rozprzestrzeniły się na cały kraj, dając początek wojnie domowej trwającej dwa lata. Początkowo rząd dążył do stłamszenia buntu, 
jednak rosnące niezadowolenie społeczne stało się początkiem zmian. W Anglii drugiej połowy XXI wieku wyeliminowano takie instytucje jak policja, armia, rząd. Najważniejszymi wartościami okazały się wolność oraz równość. Symbole dawnego systemu (jak House of Parlament czy British Museum) przestały pełnić dawną funkcję, stając się wielkimi marketami, w których mieszkańcy dokonują transakcji handlowych. Z powszechnego obiegu zniknęły pieniądze (monety i banknoty znajdują się wyłącznie w muzeum), a handel opiera się głównie na wymianie produktów niezbędnych do życia. Transformacji uległ także system kształcenia dzieci oraz młodzieży. Nacisk położono na zdobywanie praktycznych umiejętności takich jak gotowanie czy prowadzenie sklepu (Morris 1902).

Londyn przypomina piękny ogród, w którym rosną nie tylko dęby, kasztany, ale również drzewa owocowe (m.in. wiśnie, morele). W drugiej połowie XXI wieku zmienił się także sposób podróżowania; popularnym i zarazem ekologicznym środkiem transportu jest łódź, z perspektywy której narrator podziwia kwieciste, zielone łąki. W centrum zainteresowania bohatera - przybysza z innego świata - znajdują się domy (budowane z czerwonej cegły):

Każdy z nich otoczony był ogrodem, starannie utrzymanym i okrytym barwnym kobiercem kwiatów. Z drzew, które, z wyjątkiem nielicznych grup lip tu i owdzie samotnie stojących wawrzynów, zdawały się należeć do najszlachetniejszego gatunku drzew owocowych, dochodził radosny chór kosów. We wszystkich tych ogrodach zdawały się przeważać czereśnie, uginające się pod ciężarem jagód, a ilekroć zbliżyliśmy się do ogrodzenia, dzieci i młode dziewczęta podawały nam koszyczki, pełne najpiękniejszych owoców. Oczywiście, że w tym labiryncie ogrodów i domów nie mogłem rozpoznać choćby śladu dawniejszych ulic, jakkolwiek najgłówniejsze przypominały dawne linie i położenie (Morris 1902).

W powieści Morrisa pejzaż industrialny zostaje zastąpiony pejzażem agrarnym. Codzienna egzystencja Anglików koncentruje się na wytwarzaniu pięknych przedmiotów (mebli, ubrań), które mogą być przekazywane z pokolenia na pokolenie. Zaproponowany przez autora projekt przemiany świata opiera się na odbudowaniu utraconej więzi z przyrodą. Reformy wprowadzone przez Brytyjczyków (recykling, ograniczanie produktów niezbędnych do życia) okazują się niezwykle aktualne dla współczesnego czytelnika, egzystującego w epoce pogłębiającego się kryzysu klimatycznego.

Problem globalnego ocieplenia pojawia się w opowiadaniu Memoriał doktora Czang-Fu-Li (1912) Langego. Utwór ten wyróżnia się odmienną konwencją 
gatunkową i przypomina dystopię. Akcja noweli rozgrywa się w 2652 roku (zob. Szcześniak 2001: 87). Autor buduje ponurą wizję przyszłości Europy w oparciu o zmiany klimatyczne zachodzące na kontynencie. Przebywający w Akademii Nauk w Pekinie tytułowy doktor relacjonuje wyprawę naukową do Europy, która pokryta jest „niemal w całości wiekuistym śniegiem i lodem” (Lange 2003: 124). Naukowiec odkrył, że:

[...] jeszcze siedemset lat temu, tj. w pierwszej połowie XX wieku, Europa miała klimat bardzo łagodny, że np. w Kampanii Rzymskiej kwitły migdały, cytryny, eukaliptusy jak u nas we Władywostoku; że podobno Rzym stanowił niegdyś potężne imperium, że Rzymianie stworzyli prawo (!?), że (ta lodowata pustynia) był stolicą wielkiej republiki i że tu jeszcze w XVIII wieku ogłoszona została tzw. „Deklaracja prawa człowieka” (Lange 2003: 125).

Przyczyną niniejszej katastrofy ekologicznej, jak czytamy w sprawozdaniu doktora Czang-Fu-Li, był „sam człowiek, który rozzuchwalił się nadmiernie i zamierzył kulę ziemską przetworzyć, nie obliczywszy przedtem wszystkich możliwości" (Lange 2003: 125). Jego nadmierna ingerencja w ekosystem zaburzyła naturalną samoregulację planety. Wybudowany wielki kanał Carraba, łączący Amerykę Środkową z Chinami, miał sprawić, że podróżowanie stanie się szybsze, w związku z czym usprawni się również wymiana handlowa między państwami. Nikt nie przewidział dalekosiężnych konsekwencji niniejszej budowli:

Oto mianowicie gorąca woda prądu meksykańsko-norweskiego zaczęła się przelewać z Oceanu Atlantyckiego w głębie Oceanu Spokojnego z początku w niewielkich ilościach, potem zaś w coraz większych - tak, że po upływie stu lat - mniej więcej w roku 2050, Golfsztorm europejski zniknął zupełnie i, można rzec, zlodowaciał. Krainy niegdyś ciepłe, jak Irlandia, Anglia, Skandynawia, Niemcy itd., pozbawione fal prądu gorącego, zaczęły stygnąć stopniowo, oziębiać się i lodowacieć, aż zamarły całkowicie i stały się siedliskiem wiecznych śniegów i lodów; później nieco Iberia, Francja, Włochy - ogrzewane czas jakiś tchnieniem wiatrów afrykańskich - również uległy mroźnym prądom Atlantyku i również zastygły i zlodowaciały (Lange 2003: 127).

Nowoczesny kanał przyczynił się do zmian stref klimatycznych, co z kolei zwiększyło zjawisko migracji społeczeństw zamieszkujących Anglię, Irlandię, Francję czy Niemcy. Wraz z ich wędrówką w kierunku Afryki oraz Ameryki 
w kolejnych pokoleniach zmienił się także ich kolor skóry na mlecznokawowy (Lange 2003: 126), co było naturalną konsekwencją dostosowania się do nowych warunków życia. Europa przeobraziła się zaś w krainę lodu, a dawne miejsca, w których toczyło się dynamicznie życie społeczne i kulturalne, stały się lodowatą pustynią.

Lange słusznie przewidywał, że niekontrolowany rozwój nauki oraz przemysłu diametralnie wpłynie na ludzką egzystencję, a nasza przyszłość będzie ściśle uzależniona od zmian klimatycznych zachodzących na Ziemi. Jego spostrzeżenia są niezwykle aktualne, gdyż w drugiej dekadzie XXI wieku obserwujemy wzmożoną emigrację uchodźców z terenów dotkniętych różnego rodzaju kataklizmami. Na skutek przesunięcia się stref klimatycznych miejsca, które dawniej uznawano za przyjazne dla człowieka, stały się uciążliwe. Interesujące wydają się również końcowe spostrzeżenia doktora Czang-Fu-Li:

Z owych rzekomych książek pisanych wymarłym językiem paryskim, wyczytał on, że ten naród w połowie XX wieku był właśnie $\mathrm{w}$ przededniu realizacji największej reformy, jaka była od początku świata: w przededniu rozwiązania kwestii socjalnej. Że właśnie kiedy zaczęło się budowanie podstaw tej wielkiej przemiany społecznej ziemia w Europie zaczęła marznąć, temperatura średnia roczna zaczęła opadać (do 3 a nawet $2^{\circ} \mathrm{C}$ ) i wszelka inicjatywa w tej doniosłej sprawie została sparaliżowana (Lange 2003: 129-130).

Według Langego politycy w połowie XX wieku lekceważyli problemy związane z postępującymi zmianami klimatycznymi. Częściowo wynikało to z faktu, że społeczeństwo nastawione było na ciągły rozwój kosztem środowiska naturalnego, rządzący nie przewidzieli zaś skutków dynamicznej urbanizacji. Gwałtowny rozwój przemysłu sprawił, że z jednej strony społeczeństwo bogaciło się, z drugiej zaś borykało się z licznymi przewlekłymi chorobami, będącymi następstwem zanieczyszczonego powietrza.

W noweli Langego nie pojawiają się żadne informacje na temat konfliktów zbrojnych, które w obliczu klęski żywiołowej, jakim stał się głód, musiały mieć miejsce na przestrzeni wieków. W apokaliptycznej wizji pisarza pozycja danego kraju jest ściśle uzależniona od rozwoju rolnictwa. Regiony, w których uprawiane są warzywa i owoce, świadczą o potędze gospodarczej państwa. Niepokój wzmaga fakt, że z powierzchni Ziemi zniknęły niektóre gatunki zwierząt. $\mathrm{Na}$ skutek niekorzystnych warunków wyginęly konie. Na marginesie warto dodać, że wątek ten pojawił się również w powieści $W X X$ wieku. Fantazya humorystyczna (1896) Włodzimierza Zagórskiego (zob. Piechota 2015: 70-77). 
Moderniści dostrzegli destrukcyjny wpływ cywilizacji przemysłowej na życie jednostki. Nasilające się na przełomie XIX i XX wieku nastroje pesymistyczne wraz z krytyką wielkich metropolii z jednej strony stały się impulsem do poszukiwania alternatywnej przestrzeni do egzystencji. Niewątpliwie miejscem takim stały się utopie agrarne, których twórcy nawoływali do powrotu na łono natury. Z drugiej strony popularnością cieszyły się katastroficzne wizje przyszłości, przedstawiające upadek cywilizacji europejskiej. Kontynent ten był nie tylko przeludniony, ale również skażony toksycznymi substancjami. Często rewolucja zapowiadała nadciągającą apokalipsę, w której to pozbawieni jakichkolwiek zasad moralnych ludzie toczyli walkę o przetrwanie. Ich barbarzyńskie zachowanie, ukazane choćby w Cmentarzysku, stało się czytelnym znakiem zaburzonego porządku społecznego. Nieprzypadkowo u Reymonta po upadku rewolucji na zgliszczach fabryki odradza się przyroda, przypominając o fundamentalnej zasadzie, o której społeczeństwo epoki pary i elektryczności zapomniało. Życie ludzkie jest ściśle powiązane ze światem natury oraz jej cyklicznością. Budując nowoczesne społeczeństwo, nie należy zapominać o mitycznej prajedni człowieka, przyrody i Boga gwarantującej ład oraz harmonię świata (Utkowska 2004: 290). Moderniści, ukazując katastrofę społeczną czy ekologiczną, chętnie posługiwali się motywami oraz wątkami typowymi dla poetyki ekspresjonizmu. Świat zmierzający ku kosmicznej zagładzie, duchowa degradacja człowieka zanurzonego w cywilizacji przemysłowej potęgują u czytelnika uczucie niepokoju (Podraza-Kwiatkowska 2001: 71-77; Szurek 1988: 186-187). Rzeczywistość jest antynomiczna, przesiąknięta ciągłą walką dobra ze złem. Ekspresjoniści, ukazując zbliżający się kataklizm, posługiwali się hiperbolizacją, wprowadzali elementy turpistyczne, podkreślające brzydotę otaczającego świata. Istotną rolę odgrywała również kolorystyka zestawiana na zasadzie oksymoronu z dominującymi barwami czerni i czerwieni.

Analiza utworów Reymonta, Daniłowskiego, Langego i Morrisa z perspektywy ekokrytycznej odsłania estetykę modernizmu w nowej, paradoksalnie realistycznej scenerii antropocenu, w którym to stopień oddziaływania człowieka na biosferę zaburzył równowagę ekologiczną w świecie natury. Apokaliptyczne obrazy modernistów okazują się niezwykle kompatybilne z realiami naszej rzeczywistości i stanowią rodzaj międzyepokowej paraleli (XIX-XXI wiek). Uchwycony przez nich kres cywilizacji europejskiej ma zatem szerszy wymiar, gdyż w katastroficznych wizjach pisarze dostrzegli fakt, że nasza planeta jest krucha, a pogłębiający się kryzys klimatyczny diametralnie zmieni styl życia mieszkańców Ziemi. 


\section{| Bibliografia}

Bobrowska Barbara (2004), Małe narracje Prusa, słowo/obraz terytoria, Gdańsk.

Borawski Zygmunt (2018), Wirtualne zachwyty nad wertykalnym lasem, „Przekrój”, nr 3, s. 138-139.

Czeczot Katarzyna, Pospiszyl Michał (2018), Romantyczny antykapitalizm, Wydawnictwo IBL, Warszawa.

Daniłowski Gustaw (1906), Fragment pamiętnika, S. Orgelbranda Synowie, Warszawa, s. 3-46.

Gielata Ireneusz (2011), Bolesław Prus na progu nowoczesności, Wydawnictwo Akademii Techniczno-Humanistycznej, Bielsko-Biała.

Gutowski Barłomiej (2004), Secesja, SBM, Warszawa.

Gutowski Wojciech (1993), Symbolika urbanistyczna w literaturze Młodej Polski, w: Miasto - Kultura - Literatura. Wiek XIX, red. Jan Data, Wydawnictwo Gdańskie, Gdańsk, s. 64-78.

Jedlicki Jerzy (200o), Świat zwyrodniały. Lęki i wyroki krytyków nowoczesności, SIC, Warszawa.

Kolbuszewski Jacek (1992), Ochrona przyrody a kultura, Towarzystwo Przyjaciół Polonistyki Wrocławskiej, Wrocław.

Lange Antoni (2003), Memoriał doktora Czang-Fu-Li, w: tenże, W czwartym wymiarze. Opowiadania fantastyczne, Wydawnictwo Universitas, Kraków, s. 124-130.

Leopold David (2009), Introduction, w: Morris William, News From Nowhere or An Epoch of Rest. Being Some Chapters From a Utopian Romance, Oxford Univeristy Press, New York, s. VII-XXXI.

Malik Jakub (2003), Cuda epoki. Bolesław Prus o wynalazkach, technice i nowoczesności, w: Bolesław Prus. Pisarz. Publicysta. Myśliciel, red. Maria Woźniakiewicz-Dziadosz, Stanisław Fita, Wydawnictwo UMCS, Lublin, s. 397-405.

Morris William (1902), Wieści znikąd, czyli epoka spoczynku. Kilka rozdziałów utopijnego romansu, przeł. Wojciech Szukiewicz, Nakładem księgarnii H. Alteberga, Lwów, https://tinyurl.com/ktxhyf2f [dostęp: 31.05.2020].

Oramus Dominika (2010), O pomieszaniu gatunków. Science fiction a postmodernizm, TRIO, Warszawa.

Oramus Dominika (2020), Stany splątane. Fizyka a literatura współczesna, Copernicus Center Press, Kraków.

Paczoska Ewa (2010), Prawdziwy koniec XIX wieku. Śladami nowoczesności, PIW, Warszawa.

Piechota Dariusz (2015), Między utopia a melancholia. W kręu nowoczesnej i ponowoczesnej literatury fantastycznej, Norbertinum, Lublin. 
Piechota Dariusz (2020), Przestrzeń Łodzi w zwierciadle dyskursu toksyczności.

Na marginesie „Ziemi obiecanej” Władysława Stanisława Reymonta, „Humanistyka i Przyrodoznawstwo", nr 26, s. 113-130.

Podraza-Kwiatkowska Maria (2001), Literatura Młodej Polski, PWN, Warszawa.

Pułka Leszek (1996), Hołota, masa, tłum. Bohater zbiorowy w prozie polskiej 1880-1918, Wydawnictwo Uniwersytetu Wrocławskiego, Wrocław.

Reymont Władysław Stanisław (1907), Cmentarzysko, w: tenże, Na krawędzi.

Opowiadania, Gebethener i Spółka, Warszawa, s. 109-161.

Stępnik Krzysztof (1988), Formuły modelowe modernistycznej poezji ekspresjonistycznej, w: Ekspresjonizm w literaturze Młodej Polski na tle literatury polskiej i obcej XX wieku, red. Eugenia Łoch, Wydawnictwo UMCS, Lublin, s. 25-46.

Szcześniak Janina (2001), Z problematyki science fiction $w$ prozie Antoniego Langego, w: Modernistyczny wizerunek człowieka. Studia historycznoliterackie, red. Janina Szcześniak, Dariusz Trześniowski, Wydawnictwo UMCS, Lublin, s. 81-94.

Sztachelska Jolanta (1997), „Reporteryje” i reportaże. Dokumentarne tradycje polskiej prozy w 2. poł. XIX i na poczatku XX wieku, Wydawnictwo Uniwersytetu w Białymstoku, Białystok.

Szurek Jacek (1988), Tendencje ekspresjonistyczne w prozie Jerzego Żuławskiego, w: Ekspresjonizm w literaturze Młodej Polski na tle literatury polskiej oraz obcej XX wieku, red. Eugenia Łoch, Wydawnictwo UMCS, Lublin, s. 183-214. Tyszka Adam (2005), Pozytywiści wobec rewolucji 1905-1907. Szkic z dziejów świadomości polskiej, w: Rewolucja lat 1905-1907. Literatura - Publicystyka Ikonografia, red. Krzysztof Stępnik, Monika Gabryś, Wydawnictwo UMCS, Lublin, s. 19-30.

Utkowska Beata (2004), Poza powieścią. Małe formy epickie Reymonta, Universitas, Kraków.

Wilson Andrew N. (2009), The Victorians, Hutchinson, London.

\section{| Abstrakt}

DARIUSZ Piechota

Wątki ekologiczne w prozie modernistów

U schyłku XIX wieku wraz z narastającymi nastrojami dekadenckimi, pesymistyczną filozofią Schopenhauera, krytyką wielkich aglomeracji przemysłowych w literaturze pojawiły się utwory, w których moderniści zaczęli dostrzegać destrukcyjny wpływ cywilizacji przemysłowej na środowisko naturalne. Przestrzeń miasta utożsamiana 
była $\mathrm{z}$ demoralizującym siedliskiem zła, a jej wizerunek często opisywano w konwencji turpistycznej. Unoszący się dym z kominów fabryk, rzeki zatrute toksycznymi substancjami pochodzącymi z fabryk stały się symptomem nadchodzącej katastrofy ekologicznej. Moderniści poszukiwali zatem azylu w utopiach agrarnych, w których to życie człowieka zostało wpisane w odwieczny porządek panujący w naturze. Coraz częściej do głosu dochodziły marzenia o powrocie do epoki preindustrialnej. Utwory modernistów odczytywane dzisiaj z perspektywy ekokrytycznej okazują się niezwykle aktualne. Uchwycony kres cywilizacji europejskiej wydaje się mieć szerszy wymiar, gdyż w katastroficznych wizjach pisarze dostrzegli kruchość egzystencji nie tylko człowieka, ale również świata natury.

Słowa kluczowe: proza modernistów, utopia agrarna, cywilizacja przemysłowa, miasto-moloch, wątki ekologiczne

\section{| Abstract \\ DARIUSZ Piechota \\ Ecological Themes in the Prose of Modernists}

At the end of the nineteenth century, along with the growing decadent moods, the pessimistic philosophy of Schopenhauer, and the criticism of large industrial agglomerations, in literature appeared works in which modernists began to notice the destructive influence of the industrial civilization on the natural environment. The city space was identified with the demoralizing habitat of evil, and its image was often described in the turpistic convention. Smoke rising from factory chimneys, rivers poisoned with toxic substances from factories became symptoms of an impending ecological disaster. Therefore, modernists sought refuge in agrarian utopias, in which human life was inscribed in the eternal order in nature. Dreams of returning to the preindustrial era were increasingly heard. Modernist works read today from an ecocritical perspective turn out to be extremely topical. The captured end of European civilization seems to have a wider dimension, in catastrophic visions the writers have noticed the fragility of existence not only of man but also of the natural world.

Keywords: modernist prose, agrarian utopia, industrial civilization, behemoth city, ecological themes 


\section{| Biogram}

Dariusz Piechota - dr (Uniwersytet w Białymstoku), członek Laboratorium Animal Studies - Trzecia Kultura. Autor książek: Między utopia a melancholią. W kręgu nowoczesnej i ponowoczesnej literatury fantastycznej (2015); Pozytywistów spotkania z natura. Szkice ekokrytyczne (2018). Współredaktor serii Zielona Historia Literatury (Emancypacja zwierząt? [2015], Ekomodernizmy [2016], Między empatia a okrucieństwem [2018], (Nie)zapomniane zwierzęta [2021]). W kręgu jego zainteresowań badawczych znajduje się literatura drugiej połowy XIX wieku, współczesna kultura popularna oraz ekokrytyka.

E-mail: dariusz.piechota@uwb.edu.pl

ORCID: oooo-0002-7943-384X 